Pesq. Vet. Bras. 37(5):479-484, maio 2017

DOI: $10.1590 / \mathrm{S} 0100-736 \mathrm{X} 2017000500009$

\title{
Paraneoplastic hematological, biochemical, and hemostatic abnormalities in female dogs with mammary neoplasms ${ }^{1}$
}

\author{
Naila C.B. Duda ${ }^{2 *}$, Stella de F. Valle², Juliana P. Matheus ${ }^{2}$, Natália C. Angeli², Luciane \\ C. Vieira ${ }^{3}$, Luciana O. Oliveira ${ }^{3}$, Luciana Sonne ${ }^{4}$ and Felix H.D. González ${ }^{2}$
}

\begin{abstract}
Duda N.C.B., Valle S. de F., Matheus J.P., Angeli N.C., Vieira L.C., Oliveira L.O., Sonne L. \& González F.H.D. 2017. Paraneoplastic hematological, biochemical, and hemostatic abnormalities in female dogs with mammary neoplasms. Pesquisa Veterinária Brasileira 37(5):479-484. Departamento de Patologia Clínica Veterinária, Faculdade de Veterinária, Universidade Federal do Rio Grande do Sul, Avenida Bento Gonçalves 9090, Porto Alegre, RS 91540-000, Brazil. E-mail: ncbduda@hotmail.com

Paraneoplastic laboratory abnormalities are identified in several types of cancers in dogs and cats. In veterinary medicine, particularly in mammary cancer, there are few studies that correlate abnormal laboratory findings with tumor type and staging. The aim of this study was to evaluate hematological, biochemical, and hemostatic abnormalities and correlate them with mammary tumor staging in female dogs with mammary cancer. Blood samples from 24 female dogs were evaluated, and the hematological, biochemical, and hemostatic parameters were correlated with tumor staging obtained by physical examination, imaging exams, and histopathological surgical biopsies. The groups were organized according to tumor staging: group 1 (stages I and II), group 2 (stage III), and group 3 (stages IV and V). Anemia, neutrophilic leukocytosis, monocytosis, eosinophilia, thrombocytosis, hypoalbuminemia, hypocalcemia, hypoglycemia, and low blood urea were observed. The variables MCHC, TPP, and RDW were correlated with tumor staging with no clinical relevance. Thrombin time and fibrinogen were significant between the groups in the coagulation test, being associated with tumor staging. The findings suggest influence of the proinflammatory cytokines released during tumor growth.
\end{abstract}

INDEX TERMS: Hyperfibrinogenemia, mammary tumor staging, paraneoplastic syndromes, laboratory parameters.

RESUMO.- [Anormalidades hematológicas, bioquímicas e hemostáticas de origem paraneoplásica em fêmeas caninas com neoplasia mamária.] Alterações laboratoriais de origem paraneoplásica são identificadas em diversos tipos de câncer de cães e gatos. Na medicina veterinária, existem poucos estudos que correlacionam os achados laboratoriais anormais com o tipo e estadiamento tumorais, principalmente em cadelas com neoplasia mamária. 0

\footnotetext{
${ }^{1}$ Received on June 11, 2015.

Accepted for publication on July 4, 2016.

${ }^{2}$ Departamento de Patologia Clínica Veterinária, Faculdade de Veterinária, Universidade Federal do Rio Grande do Sul (UFRGS), Avenida Bento Gonçalves, 9090, Bairro Agronomia, Porto Alegre, RS 91540-000, Brazil. *Corresponding author: ncbduda@hotmail.com

${ }^{3}$ Setor de Oncologia Veterinária, Faculdade de Veterinária, UFRGS, Avenida Bento Gonçalves, 9090, Porto Alegre, RS 91540-000, Brazil.

${ }^{4}$ Setor de Patologia Veterinária, Faculdade de Veterinária, UFRGS, Avenida Bento Gonçalves, 9090, Porto Alegre, RS 91540-000, Brazil.
}

objetivo deste estudo foi avaliar as alterações hematológicas, bioquímicas e hemostáticas em cadelas com neoplasia mamária e relacioná-las com o estadiamento tumoral. Foram coletadas amostras de sangue de 24 fêmeas caninas, e os parâmetros hematológicos, bioquímicos e hemostáticos obtidos foram relacionados com o estadiamento tumoral, realizado através do exame físico, exames de imagem e avaliação histopatológica após remoção cirúrgica. Os grupos foram organizados de acordo com o estadiamento tumoral em: Grupo 1 (estádios I e II), grupo 2 (estádio III) e grupo 3 (estádios IV e V). Observou-se anemia, leucocitose neutrofílica, monocitose, eosinofilia, trombocitose, hipoalbuminemia, hipocalcemia, hipoglicemia e diminuição de ureia sanguínea. As variáveis CHCM, PPT e RDW foram relacionadas com o estadiamento tumoral, porém sem relevância clínica. Nos testes de coagulação, o TT e o fibrinogênio apresentaram diferença significativa entre os grupos, sendo associado com estadiamento tumoral. Os resultados sugerem in- 
fluência das citocinas pró-inflamatórias liberadas durante o crescimento do tumor.

TERMOS DE INDEXAÇÃO: Hiperfibrinogenemia, estadiamento tumoral mamário, síndrome paraneoplásica, parâmetros laboratoriais.

\section{INTRODUCTION}

Paraneoplastic syndromes (PNS) are clinical changes that occur at sites distant from primary tumors or from their metastases (Finora 2003). Their pathophysiology includes neoplasms and may be associated with the release of growth factors, hormones, bioactive substances, immune complexes, or cytokines, producing effects on different sites (Bergman 2013). Clinical manifestations in animals consist of hypercalcemia, cachexia, disseminated intravascular coagulation (DIC), hypoglycemia, anemia, thrombocytopenia, neutrophilic leukocytosis, among others (Finora 2003).

In veterinary medicine, particularly in mammary cancer, there are few studies that correlate abnormal laboratory findings with tumor type and staging (Stockhaus et al. 1999, Andreasen et al. 2012). The few studies on untreated animals suggest that changes in hematological, biochemical, and hemostatic parameters in cancer patients be investigated with the aim of identifying abnormalities, establishing the prognosis, and treating the syndrome prior to other therapeutic procedures, as these changes may have higher morbidity than that of the tumor itself (Bergman 2013). Therefore, the goal of the present study is to identify the most frequent changes in female dogs with mammary neoplasms and to relate these changes to tumor staging, following the modified TNM classification of canine mammary tumors (Sorenmo et al. 2013).

\section{MATERIALS AND METHODS}

Animals and blood samples. The study protocol was approved by the Animal Ethics Committee of UFRGS (CEUA, protocol 23774), and all owners authorized the procedures by signing a consent form at the time of clinical examination before sample collection. Inclusion criteria were the presence of mammary tumors and absence of co-morbidities. All dogs were submitted to a complete clinical evaluation and to imaging exa$\mathrm{ms}$ (chest X-ray and abdominal ultrasound) for the detection of metastasis.

Thirty-seven blood samples were collected from female dogs with mammary tumors between August and November 2014 at the Veterinary Teaching Hospital (HCV-UFRGS). Blood samples were collected by jugular or cephalic venipuncture into $3.2 \%$ buffered sodium citrate, dipotassium EDTA, and non-anticoagulant tubes (Vacutainer tubes, B-D). Dogs with concomitant diseases $(n=13)$, diagnosed by complementary exams, were discharged from the study and those that were eligible $(n=24)$ were submitted to a therapeutic surgical procedure, according to clinical recommendation and based on severity.

In the control group, a total of 10 healthy female owned dogs, aged 2- 6 years, regularly treated against parasites and infectious and contagious diseases, were submitted to a complete clinical examination and to hematological and biochemical evaluation. This group was used to determine reference values for hemostatic evaluation with internal validation by the laboratory.
Laboratory parameters. The complete blood count was analyzed using the ABC Vet (ABX Micros, Horiba) and the hematocrit levels were confirmed by the microhematocrit technique. For the differential count, the staining smears (Diff-Quick Stain) were evaluated by optical microscopy, and reticulocyte count was performed if hematocrit was lower than $37 \%$, by the standard method of reticulocyte enumeration through supravital staining technique (Cowgill et al. 2003). TPP was determined by refractometry. The serum chemistry panel was performed in duplicate and the mean concentrations of albumin, ALT, total calcium, creatinine, alkaline phosphatase, glucose, and urea were obtained in an automated analyzer (CM 200, Wiener Lab Group, Argentina) by colorimetric and enzymatic assays (Labtest Diagnostica, Lagoa Santa, MG, Brazil).

After venipuncture, the citrated plasma was centrifuged and frozen at $-80^{\circ} \mathrm{C}$ until duplicate analyses (performed within 3.5 months after collection) of prothrombin time (PT), activated partial thromboplastin time (APTT), thrombin time (TT), and fibrinogen (FIB) were determined by clot formation following the manufacturer's instructions (In Vitro Diagnostica, Minas Gerais, Brazil) in a HumanClot Junior analyzer (In Vitro Diagnostica, Minas Gerais, Brazil). For the D-dimer, the samples were analyzed in triplicate by the turbidimetric assay (Hemostat D-dimer, In Vitro Diagnóstica), yielding the mean of the assays.

Types of tumors and tumor staging. The surgically excised breasts and regional lymph nodes were fixed in $10 \%$ buffered formalin and submitted to histological analysis for the classification of tumors (Goldschmidt et al. 2013) and for the TNM classification of canine mammary neoplasms (Owen 1980). This classification consists of five stages ( $\mathrm{I}$ to $\mathrm{V}$ ) determined by the size of the primary tumor $(\mathrm{T})$, involvement of regional lymph nodes $(\mathrm{N})$ and presence or absence of distant metastases (M). The modified version of the original study (Sorenmo et al. 2013) recommends the classification of stages I, II and III based on tumor size: I, smaller than $3 \mathrm{~cm}$; II, between 3 and $5 \mathrm{~cm}$; and III, greater than $5 \mathrm{~cm}$. Regional lymph node metastasis represents stage IV, regardless of tumor size, and distant metastasis represents stage V. In bitches with more than one nodule in the mammary chain, the largest size was considered for histological evaluation and staging. The groups were categorized according to tumor staging, where group 1 consisted of stages I and II, group 2 represented stage III, and group 3 stood for stages IV and V.

Statistical analysis. The variables were described as median, mean, minimum value, and maximum value, and were compared between the groups according to tumor staging using the Kruskal-Wallis test. If the difference was significant, the variables were assessed by ranks and compared between the groups using Tukey's post-hoc test. A significance level of 5\% was used.

\section{RESULTS}

A total of 24 animals of different breeds with a mean age of 9.6 years (at least 6 and at most 14 years, \pm 2.1 ) were included in the study. The histological analysis of mammary tumors allowed classifying neoplasms into different tumor types and also allowed classifying them according to the TNM staging system. Following this criterion, the animals were categorized into the following groups: Group 1 (stages I and II, $\mathrm{n}=10$ ), Group 2 (stage III, $\mathrm{n}=8$ ), and Group 3 (stages IV and V, $\mathrm{n}=6$ ) (Table 1).

Table 2 shows a significant difference in $\mathrm{MCHC},(\mathrm{P}=0.039)$, TPP $(\mathrm{P}=0.017)$, and RDW ( $\mathrm{P}=0.004)$ between the groups. Hematological disorders included anemia $(25 \%, n=6)$, neutrophilic leukocytosis $(45.8 \%, n=11)$, monocytosis $(25 \%, n=6)$, 
Table 1. Histological classification, TNM staging system (I to $\mathrm{V}$ ) classification, and distribution of groups ( 1 to 3 ) of female dogs with mammary tumors

\begin{tabular}{|c|c|c|c|c|}
\hline Histological classification $^{a}$ & $\mathrm{n}$ & $\%$ & TNM staging $^{\mathrm{b}}$ & Groups \\
\hline Carcinoma in situ & 2 & 8.3 & III & 2 \\
\hline Complex-type carcinoma & 4 & 16.7 & $\begin{array}{l}\text { I (n=1), II }(\mathrm{n}=1) \\
\text { and III }(\mathrm{n}=2)\end{array}$ & 1,2 \\
\hline Simple-type carcinoma & 8 & 33.3 & I, II, III, IV and V & $1,2,3$ \\
\hline Tubulopapillary carcinoma & 4 & 16.7 & $\begin{array}{l}\text { I ( }(\mathrm{n}=1), \text { II }(\mathrm{n}=1) \\
\text { and IV (n=2) }\end{array}$ & 1 and 3 \\
\hline Solid carcinoma & 2 & 8.3 & II $(n=1)$ and $V(n=1)$ & 1 and 3 \\
\hline Anaplastic carcinoma & 2 & 8.3 & II $(n=1)$ and $V(n=1)$ & 1 and 3 \\
\hline $\begin{array}{l}\text { Sarcoma (myoepithelial } \\
\text { osteosarcoma) }\end{array}$ & 1 & 4.2 & III $(n=1)$ & 2 \\
\hline Carcinosarcoma & 6 & 25 & $\begin{array}{l}\text { I ( }(n=1), \text { II }(n=1), \\
\text { III }(n=2), \operatorname{IV~}(n=2)\end{array}$ & $1,2,3$ \\
\hline Myoepithelioma & 1 & 4.2 & III $(n=1)$ & 2 \\
\hline Mixed-tumor carcinoma & 2 & 8.3 & $\mathrm{I}(\mathrm{n}=2)$ & 1 \\
\hline
\end{tabular}

a Based on the classification proposed by Goldschmidt et al. (2013), ${ }^{\mathrm{b}} \mathrm{Ba}-$ sed on the classification proposed by Owen (1980) and modified by Sorenmo et al. (2013). and eosinophilia $(33.3 \%, \mathrm{n}=8)$. In serum biochemistry (Table 3), no significant difference was observed between the groups; however, hypoalbuminemia $(33.3 \%, \mathrm{n}=8)$, hypocalcemia $(79.2 \%, n=19)$, low serum urea levels $(41.7 \%, n=10)$, and hypoglycemia $(8.3 \%, \mathrm{n}=2)$ were detected.

As shown in Table 4, there was significant difference in $\mathrm{PT}(\mathrm{P}=0.022)$, TT $(\mathrm{P}=0.019)$, and fibrinogen $(\mathrm{P}=0.002)$ between the groups (Fig.1). The difference in PT observed in the Kruskal-Wallis test was not detected in the Post-Hoc test. A significant difference was noted between the control group and Group $1(\mathrm{P}=0.022)$ and between groups 1 and $2(\mathrm{P}=0.043)$ regarding $\mathrm{TT}$, and the median and mean for Group 1 were lower than those obtained for the control group. Higher fibrinogen levels were observed in 16 animals $(66.7 \%)$ in the three groups, and these levels increased with tumor staging, being more remarkable in groups 2 and 3 compared with the control group $(\mathrm{P}=0.001$ and $\mathrm{P}=0.006$, respectively).

No differences were seen for D-dimer and platelet count, even though the rates of $16.67 \%(n=4)$ and $33.33 \%$

Table 2. Hematological parameters of female dogs with mammary neoplasms $(n=24)$ per group according to the TNM staging system

\begin{tabular}{|c|c|c|c|c|c|c|c|c|}
\hline \multirow[t]{2}{*}{ Variable } & \multirow[t]{2}{*}{ Reference* } & \multicolumn{2}{|c|}{ Group 1 (stages I and II; $\mathrm{n}=10$ ) } & \multicolumn{2}{|c|}{ Group 2 (stage III; n=8) } & \multicolumn{2}{|c|}{ Group 3 (stages IV and V; $n=6$ ) } & \multirow[t]{2}{*}{$\mathrm{P}$} \\
\hline & & Median (range) & Mean & Median (range) & Mean & Median (range) & Mean & \\
\hline $\operatorname{RBC}\left(10^{6} / \mu \mathrm{L}\right)$ & $5.5-8.5$ & $6.2(2.6-7.5)$ & 5.8 & $5.5(4.4-7.9)$ & 5.8 & $6.6(4.2-7.7)$ & 6.4 & 0.474 \\
\hline $\mathrm{HGB}(\mathrm{g} / \mathrm{dL})$ & $12-18$ & $15.6(5.9-18.6)$ & 14.5 & $12.9(10.3-16.8)$ & 13.3 & $14.6(8.6-17)$ & 15.9 & 0.415 \\
\hline HCT $(\%)$ & $37-55$ & $45.5(17-52)$ & 41.4 & $38.5(31-50)$ & 39.5 & $46(26-50)$ & 43.2 & 0.576 \\
\hline MCV (fL) & $60-77$ & $71.1(66.4-75.6)$ & 70.8 & $69.0(61.4-74.4)$ & 68.6 & $67.6(61.9-70.4)$ & 66.8 & 0.149 \\
\hline MCHC (g/dL) & $32-36$ & $34.8(33.4-35.9)$ & $34.9^{\mathrm{a}}$ & $33.7(32.0-35.4)$ & $33.7^{\mathrm{b}}$ & $33.9(33.1-34.8)$ & $33.9^{\mathrm{a}, \mathrm{b}}$ & 0.039 \\
\hline $\mathrm{TPP}(\mathrm{g} / \mathrm{L})$ & $60-80$ & $72(60-78)$ & $69.6^{\mathrm{b}}$ & $68(60-82)$ & $69^{\mathrm{b}}$ & $84(70-88)$ & $82^{a}$ & 0.017 \\
\hline RDW (\%) & $14-17$ & $13.6(12.2-14.3)$ & $13.5^{\mathrm{b}}$ & $14.7(13.8-16)$ & $14.8^{\mathrm{a}}$ & $14.5(13-17.1)$ & $14.7^{\mathrm{a}}$ & 0.004 \\
\hline Platelets $\left(10^{3} / \mu \mathrm{L}\right)$ & $200-500$ & $452(223-771)$ & 475 & $472(258-588)$ & 445 & $357(308-606)$ & 414 & 0.827 \\
\hline Total WBC $\left(10^{3} / \mu \mathrm{L}\right)$ & $6-17$ & $10.1(6.9-39.4)$ & 14.1 & $18.9(8.6-24)$ & 18.1 & $16.4(8.2-20.8)$ & 15.2 & 0.202 \\
\hline BAND NEU $\left(10^{3} / \mu \mathrm{L}\right)$ & $0-0.3$ & 0 & 0 & $0(0-0.2)$ & 0.5 & 0 & 0 & 0.207 \\
\hline SEG NEU $\left(10^{3} / \mu \mathrm{L}\right)$ & $3-11.5$ & $7.5(4-34.3)$ & 10.8 & $14.7(6.4-21.8)$ & 13.7 & $10.2(5.9-16.2)$ & 10.9 & 0.124 \\
\hline $\operatorname{EOS}\left(10^{3} / \mu \mathrm{L}\right)$ & $0.1-1.2$ & $0.6(0.1-1.7)$ & 678.6 & $1.4(0.2-4.7)$ & 1.5 & $0.8(0.1-5.5)$ & 1.5 & 0.206 \\
\hline $\operatorname{LYM}\left(10^{3} / \mu \mathrm{L}\right)$ & $1-4.8$ & $1.4(1-2.7)$ & 1.6 & $1.2(0.2-2.9)$ & 1.5 & $1.8(1.1-2.7)$ & 1.9 & 0.387 \\
\hline MONO $\left(10^{3} / \mu \mathrm{L}\right)$ & $0.1-1.3$ & $0.7(0.2-3.5)$ & 1 & $1.2(0.5-1.9)$ & 1.1 & $0.8(0.4-1.5)$ & 0.9 & 0.725 \\
\hline
\end{tabular}

Data expressed as median (range) and mean. Significance obtained from the Kruskal-Wallis test. Significant differences $(\mathrm{p}<0.05)$ within a row are marked with different superscript letters. RBC = erythrocytes, HGB = hemoglobin, HCT = hematocrit, MCV = mean corpuscular volume, $\mathrm{MCHC}=$ mean corpuscular hemoglobin concentration, $\mathrm{TPP}=$ total plasma protein, RDW = red cell distribution width, Total WBC $=$ total leukocytes, BAND NEU = band neutrophils, SEG NEU = neutrophils, EOS = eosinophils, LYM = lymphocytes, MONO = monocytes.

* Reference values obtained from the literature (Rizzi et al. 2010).

Table 3. Biochemical parameters in female dogs with mammary neoplasms $(n=24)$ per group according to the TNM staging system

\begin{tabular}{|c|c|c|c|c|c|}
\hline Variable & Reference* & Group 1 (stages I and II; $\mathrm{n}=10$ ) & Group 2 (stage III; $\mathrm{n}=8$ ) & Group 3 (stages IV and V; $n=6$ ) & $\mathrm{P}$ \\
\hline \multirow[t]{2}{*}{ Albumin (g/L) } & $26-33$ & $29.31(22.53-35.33)$ & $24.37(22.18-29.8)$ & $27.98(18.43-32.89)$ & 0.265 \\
\hline & & 29.3 & 25.69 & 26.96 & \\
\hline \multirow[t]{2}{*}{$\operatorname{ALT}(\mathrm{U} / \mathrm{L})$} & $<102$ & $35.22(23.59-99.96)$ & $36.4(22.47-53.63)$ & $28.34(18-39-42-66)$ & 0.222 \\
\hline & & 44.04 & 36.1 & 28.18 & \\
\hline \multirow[t]{2}{*}{ Calcium (mg/dL) } & $9-11.3$ & $8.38(5.18-10.98)$ & $8.42(6.52-10.81)$ & $8.09(6.70-9.24)$ & 0.915 \\
\hline & & 8,38 & 8.52 & 8.05 & \\
\hline \multirow[t]{2}{*}{ Creatinine $(\mathrm{mg} / \mathrm{dL})$} & $0.5-1.5$ & $0.93(0.48-1.41)$ & $0.89(0.76-1.34)$ & $0.77(0.6-1.25)$ & 0.610 \\
\hline & & 0.93 & 0.98 & 0.86 & \\
\hline \multirow[t]{2}{*}{ ALP (U/L) } & $<156$ & $43.75(6.30-141.00)$ & $80.31(63.69-135.2)$ & $69.54(17.80-90.77)$ & 0.235 \\
\hline & & 54.82 & 84.74 & 62.05 & \\
\hline \multirow[t]{2}{*}{ Glucose $(\mathrm{mg} / \mathrm{dL})$} & $65-118$ & $93.72(58.78-134.20)$ & $87.21(69.70-114.60)$ & $92.63(63.69-104.08)$ & 0.919 \\
\hline & & 91.84 & 89.19 & 88.88 & \\
\hline \multirow[t]{2}{*}{ Urea (mg/dL) } & $21-60$ & $29.51(16.98-55.31)$ & $19.29(11.31-60.20)$ & $30.75(12.38-41.09)$ & 0.633 \\
\hline & & 31.75 & 28.21 & 28.5 & \\
\hline
\end{tabular}

Data expressed as median (min-max) and mean. Significance obtained from the Kruskal-Wallis test. ALT = alanine aminotransferase, ALP = alkaline phosphatase. *Laboratory reference values. 
Table 4. Hemostatic parameters in female dogs with mammary neoplasms $(n=24)$ per group according to the TNM stating system

\begin{tabular}{lccccc}
\hline Variable & Control group & $\begin{array}{c}\text { Group 1 (stages I } \\
\text { and II; n=10) }\end{array}$ & $\begin{array}{c}\text { Group 2 (stage III; } \\
\mathrm{n}=8)\end{array}$ & $\begin{array}{c}\text { Group 3 (stages IV } \\
\text { and V; n=6) }\end{array}$ & $P$ \\
\hline PT (s) & $6.3(5.80-6.85)$ & $5.88(5.55-6.85)$ & $5.95(5.40-6.30)$ & $6.4(6-6.75)$ & \\
& $6.34^{\mathrm{a}, \mathrm{b}}$ & $6.03^{\mathrm{a}, \mathrm{b}}$ & $5.91^{\mathrm{b}}$ & $6.4^{\mathrm{a}}$ & 0.022 \\
APTT (s) & $16.55(14.65-18.25)$ & $15.2(14.05-17.85)$ & $16.98(14.1-18.05)$ & $16.95(15.6-21.9)$ & 0.131 \\
& 16.60 & 15.65 & 16.59 & 18.01 & \\
TT (s) & $8.7(8.20-9.50)$ & $7.1(6.20-9.30)$ & $8.85(7.9-9.7)$ & $8.1(6.9-9.4)$ & 0.019 \\
& $8.78^{\mathrm{a}}$ & $7.5^{\mathrm{b}}$ & $8.8^{\mathrm{a}}$ & $8.07^{\mathrm{a}, \mathrm{b}}$ & \\
FIB (mg/dL) & $88(70.5-121)$ & $101.5(82.0-314.0)$ & $224(86.5-353)$ & $188.25(82.5-355)$ & 0.002 \\
& $87.18^{\mathrm{b}}$ & $137.27^{\mathrm{a}, \mathrm{b}}$ & $219.82^{\mathrm{a}}$ & $199.17^{\mathrm{a}}$ & \\
D-dimer (ng/ml) & $59(30-88)$ & $44(2-86)$ & $30(2-464)$ & $58(30-198)$ & 0.237 \\
& 54.96 & 43.7 & 105.25 & 81.34 &
\end{tabular}

Data expressed as median (min-max) and mean. Significance obtained from the Kruskal-Wallis test. Significant differences $(\mathrm{p}<0.05)$ within a row are marked with different superscript letters. PT $=$ prothrombin time, APTT $=$ activated partial thromboplastin time, $\mathrm{TT}=$ thrombin time, $\mathrm{FIB}=$ fibrinogen.
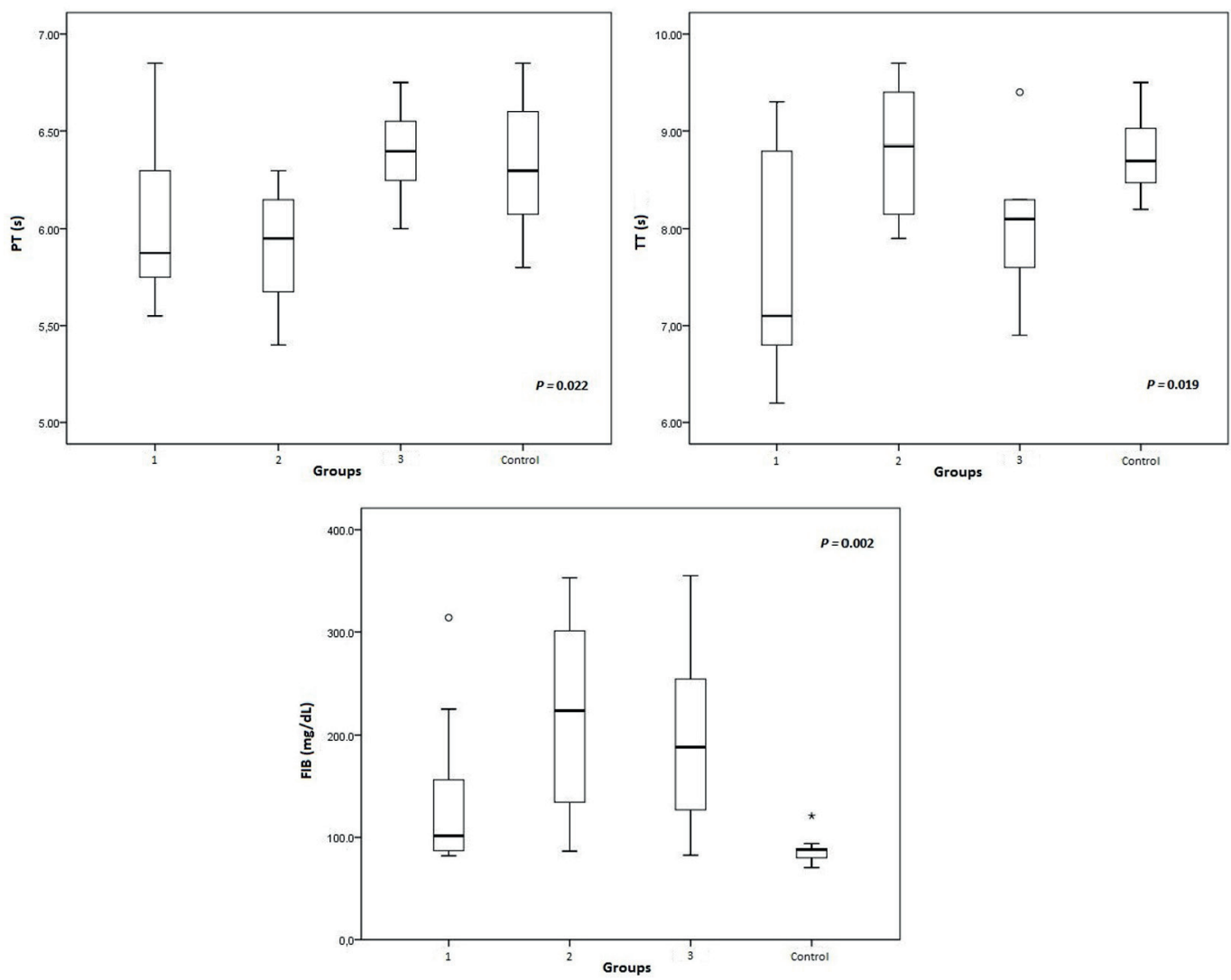

Fig.1. Boxplot of PT, TT and FIB according to tumor staging. The top and bottom of the box indicate the upper and lower quartiles, respectively; the horizontal line represents the median value, and the vertical line goes from the minimum value to the maximum value; the circle and the asterisk represent the outliers. Significance obtained by the Kruskal-Wallis test.

$(\mathrm{n}=8)$ revealed elevated D-dimer levels and thrombocytosis, respectively.

\section{DISCUSSION}

The mild to moderate nonregenerative (absence of reticulocytosis), normocytic, normochromic anemia observed in six dogs has already been associated with cancer in small animals and is one of the most frequent paraneoplastic signs (Madewell \& Feldman 1980, Finora 2003, Bergman 2013). The mechanism of this disorder is associated with the secretion of cytokines such as interleukin 1 (IL-1) and tumor necrosis factor alpha (TNF- $\alpha$ ) by tumor cells. These cytokines sequester iron, reduce erythrocyte half-life (IL1), and also reduce erythropoietin release (TNF and IL-6). In addition, microangiopathic hemolytic anemia and immune-mediated hemolytic anemia have already been described in mammary carcinoma (Mangieri 2009); however, the most relevant cause of nonregenerative anemia in cancer patients is believed to be anemia of chronic disease, also known as anemia of inflammation (Childress 2012). There are few studies that evaluate the association of hematological condition with mammary neoplasm, but the results are 
similar, considering that normocytic, normochromic anemia was previously observed in $11.2 \%(11 / 161)$ of dogs (Silva et al. 2014), whereas another study only indicated a reduction in erythrocyte levels in bitches with mammary carcinoma compared with a control group (Estrela-Lima et al. 2012).

In dogs with primary neoplasms, neutrophilic leukocytosis, detected in $45.8 \%$ of sampled animals, may be attributed to inflammation or tissue necrosis associated with mammary cancer or triggered by chronic stress (Childress 2012). In malignant cases, there may be an elevation in the circulating levels of hematopoietic growth factors, causing an increase in the production and release of neutrophils; however, this mechanism has not been fully elucidated yet. Moreover, IL-1 and TNF- $\alpha$ also can induce neutrophilia by stimulating the production of growth factors (Harvey 2012). In the present study, six (25\%) out of 11 animals with neutrophilic leukocytosis had concomitant monocytosis, which corroborates the presence of a chronic infection, tumor, or tissue necrosis (Stockham et al. 2003) in female dogs with mammary neoplasms. Eosinophilia, detected in $33.3 \%$ of sampled animals, has already been associated with several tumors and with anaplastic mammary carcinoma (Losco 1986), even though it is seldom observed in patients with solid tumors (Childress 2012). It is assumed that other cytokines may be released during tumor growth, such as TNF- $\alpha$, IL-1, IL-6, and IL-5, one of the cytokines in charge of eosinophil production (Radin \& Wellman 2010). Nonetheless, parasitic infection is not ruled out as the cause for eosinophilia, especially because no parasitological stool examination was performed in the present study.

Hypoalbuminemia, seen in $33.3 \%$ of the animals $(n=8)$, may be related to the inflammation caused by the neoplastic process, as albumin is a negative acute-phase protein that tends to reduce its serum levels after an inflammatory stimulus (Cerón et al. 2005). On the other hand, protein deficiency should be taken into account in the interpretation of hypoalbuminemia, given that $16.7 \%$ of the dogs revealed a concomitant decrease in serum urea concentrations, with no evidence of liver disease on the abdominal ultrasound.

Variations in calcium levels have not been clearly established, and nor have they been reported regularly in female dogs with mammary tumor, although paraneoplastic hypercalcemia has been described in mammary carcinomas and adenocarcinomas (Sellon 2008, Bergman 2013). Hypocalcemia was detected in $79.2 \%(n=19)$ of sampled animals, and it was assumed that its mechanism is related to abnormal calcitonin secretion by some mammary tumors, as previously described in humans (Hillyard et al. 1976). Of these dogs, $29.2 \%(n=7)$ presented with hypoalbuminemia, which may reduce circulating calcium levels in view of the fact that plasma calcium is carried by this protein. Thus, it is suggested that hypocalcemia be investigated by measuring ionized calcium levels in order to determine its etiology.

In human medicine, thrombocytosis is a clinically important finding often detected in cancer patients, but there is a paucity of reports on this condition in veterinary oncology (Childress 2012, Bergman 2013). In dogs, studies have given contradictory results, although it is a common finding (Hammer 1991), observed in 33.3\% of sampled animals. Despite the fact that its mechanism is not well-known in veterinary medicine, it has been suggested that epinephrine-induced splenic contraction and the release of pro-angiogenic tumor proteins and inflammatory cytokines (e.g., IL-1 and IL-6) or hematopoietic growth factors (Saavedra et al. 2011, Childress 2012) secreted or induced by the tumor may contribute to thrombocytosis. The result obtained may indicate that the actual incidence of thrombocytosis in animals with cancer is underestimated (Childress 2012).

Abnormal clotting time in cancer patients may also be associated with the release of proinflammatory cytokines, which increase the use of coagulation factors (Andreasen et al. 2012). In female dogs with breast tumors, the results were similar to those of previous studies on animals with carcinoma (Saavedra et al. 2011) and when associated with tumor progression in animals with different types of tumors (Andreasen et al. 2012).

Hyperfibrinogenemia, seen in $66.7 \%$ of the animals, across the five tumor stages, with differences between groups 2 and 3, may be related to progression and extent of the cancer in canine (Andreasen et al. 2012) and human (Rickles et al. 1992) patients. In a study of female dogs with mammary carcinoma, elevated fibrinogen levels were more evident in stages III and IV (Stockhaus et al. 1999). These findings may be explained by the fact that this protein increases its biosynthesis because of inflammation, stress, or infection secondary to acute-phase response and to disseminated malignancy (Herring \& McMichael 2012), due to the tissue damage caused by infiltrative tumor growth (Kies et al. 1980). In animals with cancer, high fibrinogen levels may be attributed to the inflammatory process with secretion of IL-6 (Saavedra et al. 2011). However, the association with progression of the breast tumor is important and commands attention as, in another study, hyperfibrinogenemia was associated with hypercoagulability syndromes (Saavedra et al. 2011).

In the present study, elevation of D-dimer levels was associated with inflammation triggered by the neoplastic process in that $16.7 \%(4 / 24)$ of sampled animals concomitantly had high fibrinogen concentrations $(209-355 \mathrm{mg} /$ dL). Of these animals, two belonged to Group 3, which is consistent with a later study that detected remarkable increases in D-dimer and fibrinogen levels in canine patients with distant metastases compared with patients with invasive local disease (Andreasen et al. 2012). Although no significant difference exists between the groups, the findings suggest a possible relationship between D-dimer levels and tumor staging, indicating that patients with advanced-stage disease may present with consumption coagulopathy.

\section{CONCLUSIONS}

The hematological and biochemical findings observed in this study suggest that mammary neoplasms induce a paraneoplastic syndrome, possibly due to the inflammatory cytokines and growth factors secreted by the tumor. Hyperfibrinogenemia and elevation of D-dimer values in 
some animals suggest association of the analyzed parameters with tumor extent and progression.

The findings demonstrate the necessity for laboratory investigation, as the paraneoplastic syndrome has a negative impact on treatment, prognosis, and survival of female dogs with mammary neoplasms.

Acknowledgements.- We thank CAPES for the research fellowship grant and for financial support, and Dr. Ana Paula Ravazzolo, from the Laboratory of Immunology and Molecular Biology of Universidade Federal do Rio Grande do Sul, Porto Alegre, Brazil, for technical support.

\section{REFERENCES}

Andreasen E.B., Tranholm M., Wiinberg B., Markussen B. \& Kristensen A.T. 2012. Haemostatic alterations in a group of canine cancer patients are associated with cancer type and disease progression. Acta Vet. Scand. 54:1-8.

Bergman P.J. 2013. Paraneoplastic syndromes, p.83-97. In: Withrow S.J., Vail D.M. \& Page R.L. (Eds), Withrow \& MacEwen's Small Animal Clinical Oncology. 5th ed. Saunders Elsevier, St Louis.

Cerón J.J., Eckersall P.D. \& Martínez-Subiela S. 2005. Acute phase proteins in dogs and cats: current knowledge and future perspectives. Vet. Clin. Pathol. 34:85-99.

Childress M.O. 2012. Hematologic abnormalities in the small animal cancer patient. Vet. Clin. North Am., Small Anim. Pract. 42:123-55.

Cowgill E.S., Neel J.A. \& Grindem C.B. 2003. Clinical application of reticulocyte counts in dogs and cats. Vet. Clin. Small Anim. 33:1223-1244.

Estrela-Lima A., Araújo M.S.S., Costa-Neto J.M., Ribeiro L.G.R., Damasceno K.A., D’Assis M.J.M.H., Martins-Filho O.A., Teixeira-Carvalho A., Serakides R. \& Cassali G.D. 2012. Understanding of the immunological heterogeneity of canine mammary carcinomas to provide immunophenotypic features of circulating leukocytes as clinically relevant prognostic biomarkers. Breast Cancer Res. Treat. 131:751-763.

Finora K. 2003. Common paraneoplastic syndromes. Clin. Tech. Small Anim. Pract. 18:123-126.

Goldschmidt M., Peña L., Rasotto R. \& Zappulli V. 2013. Classification and grading of canine mammary tumors. Vet. Pathol. 48:117-131.

Hammer A.S. 1991. Thrombocytosis in dogs and cats: a retrospective study. Comp. Haematol. Int. 1:181-186.

Harvey J.W. 2012. Evaluation of leucocytic disorders, p.122-176. In.: Ibid. (Ed.), Veterinary Hematology: a diagnostic guide and color atlas. Saunders Elsevier, St Louis.
Herring J. \& McMichael M. 2012. Diagnostic approach to small animal bleeding disorders. Top. Companion Anim. Med. 27:73-80.

Hillyard V., Coombes R.C., Greenberg P.B., Galante S.L. \& Macyntire I. 1976. Calcitonin in breast and lung cancer. Clin. Endocrinol. 5:1-8.

Kies M.S., Posch Jr J.J., Giolma J.P. \& Rubin R.N. 1980. Hemostatic function in cancer patients. Cancer 15:831-837.

Losco P.E. 1986. Local and peripheral eosinophilia in a dog with anaplastic mammary carcinoma. Vet. Pathol. 23:536-538.

Madewell B.R. \& Feldman B.F. 1980. Characterization of anemias associated with neoplasia in small animals. J. Am. Vet. Med. Assoc. 176:419425.

Mangieri J. 2009. Síndromes Paraneoplásicas, p.237-252. In: Daleck C.R., De Nardi R.B. \& Rodaski S. (Eds), Oncologia em Cães e Gatos. Roca, São Paulo.

Owen L.N. 1980. TNM Classification of Tumors of Domestic Animals. World Health Organization, Geneva, p.16-20.

Radin M.J. \& Wellman M.L. 2010. Granulopoiesis, p.43-49. In: Weiss D.J. \& Wardrop K.J. (Eds), Schalm's Veterinary Hematology. 6th ed. Wiley-Blackwell, Ames.

Rickles F.R., Levine M. \& Edwards R.L. 1992. Hemostatic alterations in cancer patients. Cancer Metastasis Rev. 11:237-248.

Rizzi T.E., Meinkoth J.H. \& Clinkenbeard K.D. 2010. Normal hematology of the dog, p.799-810. In: Weiss D.J. \& Wardrop K.J. (Eds), Schalm's Veterinary Hematology. 6th ed. Wiley-Blackwell, Ames.

Saavedra P.V., García A.L., López S.Z. \& Couto G. 2011. Hemostatic abnormalities in dogs with carcinoma: a thromboelastographic characterization of hypercoagulability. Vet. J. 190:78-83.

Sellon R.K. 2008. Paraneoplastic Syndromes in Small Animal Medicine. Abstr. Eur. Vet. Conf. Voorjaarsdagen, p.133-134.

Silva A.H.C., Silva D.M., Ribas C.R., Dittrich R.L., Dornbusch P.T. \& Guérios S.D. 2014. Alterações no hemograma de cadelas com neoplasia mamária. Cienc. Anim. Bras. 15:87-92.

Sorenmo K.U., Worley D.R. \& Goldschmidt M.H. 2013. Tumors of the mammary gland, p.538-56. In: Withrow S.J., Vail D.M. \& Page R.L. (Eds), Small Animal Clinical Oncology. 5th ed. Saunders Elsevier, St Louis.

Stockham S.L., Keeton K.S. \& Szladovits B. 2003. Clinical assessment of leukocytosis: distinguishing leukocytosis caused by inflammatory, glucocorticoid, physiologic, and leukemic disorders or conditions. Vet. Clin. North Am., Small Anim. Pract. 33:1335-1357.

Stockhaus C., Kohn B., Rudolph R., Brunneberg L. \& Giger U. 1999. Correlation of haemostatic abnormalities with tumor stage and characteristics in dogs with mammary carcinoma. J. Small Anim. Pract. 40:326-331. 